\title{
Penggunaan Instagram Terhadap Citra Diri Mahasiswa
}

\author{
${ }^{1}$ Sri Rejeki, ${ }^{2}$ Euis Komalawati ${ }^{*}{ }^{3}$ Poppy Indriyanti \\ ${ }^{1,2 \& 3}$ Institut Ilmu Sosial dan Manajemen STIAMI \\ Program Studi Manajemen Komunikasi - Fakultas Ilmu Sosial dan Ilmu Manajemen \\ Email: ${ }^{1}$ srejeki608@gmail.com; ${ }^{2}$ komalawatieuis@gmail.com* \\ * corresponding author
}

Keywords:

Instagram usage,

Social media,

Self-image
Instagram is one of the social media that has the concept of visual interaction. Various photo and video content on Instagram sometimes triggers and influences people to form a different self-image to their lives in the real world. The purpose of this study was to find out the effect of Instagram use on student self-image. The independent variable is Instagram Usage, and the dependent variable is Selfimage. This research uses quantitative methods, with data collection techniques using questionnaires, documentation, and literature studies. The data analysis method uses a validity and reliability test, product-moment, correlation coefficient, determination coefficient, hypothesis test, and simple linear regression test. Data processing using SPSS program version 25.00. The number of respondents was 93 people out of 1230 Communication Management students of the STIAMI Institute. Sampling technique using simple random sampling with Slovin formula. Based on Dramaturgy Theory about self-image, the results also showed in the T-test hypothesis was accepted, and the product-moment correlation test stated there is a significant positive relationship between Instagram use and self-image. The confines determination test results showed that Instagram's effect on self-image has a fairly high percentage. $R$ Square value is 0.638 or $63.8 \%$. With a high percentage value, Instagram users, especially students, should be smarter and wiser to use Instagram. With a positive motive of use, it will not cause a bad selfimage of a person.

\section{PENDAHULUAN}

Teknologi berbasis internet telah melahirkan media baru yang dikenal dengan media online. Media online sangat dekat dengan kehidupan manusia sehari-hari dan memberikan banyak manfaat terutama dalam berinterkasi sosial dan penyebaran informasi dengan mudah dan luas.

Munculnya media online sangat bermanfaat bagi masyarakat, salah satunya yaitu media sosial. Pada umumnya media sosial juga disebut dengan Social Network, Sosial Networking Sites, dan Communication Network. Kehadirannya menjadikan masyarakat dapat terhubung satu sama lain secara online tanpa adanya hambatan geografis, ruang, dan waktu.

Media sosial menjadi bagian dari media online yang sangat eksis di kalangan masyarakat. Hampir seluruh lapisan masyarakat menggunakan media sosial untuk berinteraksi dan mendapatkan informasi setiap harinya, bahkan eksistensinya kini mengalahkan media konvensional seperti televisi dan media cetak. Dan salah satu media sosial yang kini begitu populer adalah Instagram. Instagram banyak digunakan oleh kalangan usia muda, salah satunya yaitu kalangan mahasiswa. Mereka menggunakan Instagram sebagai sarana komunikasi dan juga berinteraksi sosial yang akhirnya dapat berdampak pada pencitraan dirinya.

Penggunaan Instagram di kalangan mahasiswa banyak digunakan untuk eksistensi diri yang menimbulkan rasa kepuasan tersendiri dalam diri. Jangkauan dalam interaksi sosial pun begitu luas sehingga tidak ada batasan bagi mereka untuk menyaring informasi yang baik dan buruk bagi dirinya.

Instagram memiliki konsep media sosial yang unik dan praktis. Dalam konsep interaksinya seseorang dapat membagikan suatu konten berupa gambar ataupun tayangan video yang disertai dengan caption atau kalimat pendek. Selain itu terdapat juga fitur direct massage untuk saling bertukar pesan secara instan. 
Konsep interaksi sosial yang mudah dan berupa visual inilah yang akhirnya membuat banyak masyarakat begitu gemar menggunakan Instagram, khususnya di kalangan mahasiswa. Mahasiswa identik menyukai hal-hal yang bersifat instan, praktis dan juga modern. Dengan adanya Instagram, seorang mahasiswa dapat saling berinteraksi satu sama lain dengan membagikan foto atau video yang menggambarkan citra dirinya. Biasanya pengguna Instagram juga akan saling berinteraksi dengan mengomentari foto ataupun video. Adanya penilaian dari orang lain terkait foto atau video yang di posting di akun Instagram milik seseorang, menghadirkan kepuasan tersendiri terutama bagi kalangan mahasiswa yang notabene sedang berada dalam fase pembentukan citra diri. Banyak kasus yang terjadi di berbagai kampus, beberapa mahasiswa bahkan berani memposting foto tentang dirinya yang bernilai konten negatif. Dengan percaya diri, ia justru merasa bangga meskipun telah banyak memicu kontroversi dan penilaian negatif terhadap dirinya.

Penggunaan Instagram pun terbukti tidak hanya dimanfaatkan sebagai sarana untuk berinteraksi sosial. Beragam konten foto dan video di Instagram juga terkadang banyak memicu dan mempengaruhi seseorang untuk membentuk citra diri yang berbeda dengan kehidupannya di dunia nyata.

Beberapa kajian tentang penggunaan Instagram telah dilakukan, antara lain oleh Nabila yang menunjukkan bahwa Citra diri yang tampak pada Mahasiwa adalah tentang over confidence. Hal ini ditunjukkan dari beberapa informan yang dipilih oleh peneliti (Putri \& Farida, 2018). Peneliti lain menunjukkan kalangan selebriti seperti Bara Pattiradjawane juga menggunakan Instagram sebagai alat personal branding dalam membentuk citra diri menggunakan 8 konsep personal branding Peter Montoya secara optimal yaitu spesialisasi, kepemimpinan, kepribadian, perbedaan, penampilan, persatuan, persatuan, tekad, dan niat baik (Restusari \& Farida, 2019).

Penggunaan Instagram tersebar di berbagai daerah karena kekuatan media sosial ini menembus ruang dan waktu. Sebuah kajian menunjukkan kebiasaan masyarakat Kota Pekanbaru memainkan media sosial Instagram telah menjadi kebutuhan bagi mereka, hal-hal yang didapatkan dari para pengguna media sosial Instagram seperti informasi, menambah pertemanan membuat mereka selalu ingin memainkannya (Irawan \& Yusuf, 2017).

Sementara itu, hasil penelitian lain menunjukkan motif paling tinggi pengguna Instagram adalah hiburan dengan nilai 66\% terhadap citra diri yaitu Ideal Social Self Image 72\% (Rarasingtyas \& Maturbongs, 2019). Selain itu, tingkat kepercayaan diri seseorang juga akan meningkat karena penggunaan media sosial tersebut (Sharma \& Sahu, 2013).

Berdasarkan fenomena tentang maraknya penggunaan Instagram di kalangan mahasiswa sebagai sarana pencitraan diri, maka penelitian ini bertujuan untuk mengetahui Pengaruh Penggunaan Instagram Terhadap Citra Diri Mahasiswa dengan populasi yang dipilih adalah mahasiswa Program Studi Manajemen Komunikasi Institut Ilmu Sosial dan Manajemen Stiami Jakarta.

\section{KERANGKA TEORITIS}

\section{Media Sosial}

Menurut Andreas Kaplan dan Michael Haenlein (Cahyono, 2016) mengungkapkan, "media sosial adalah sebuah kelompok aplikasi berbasis internet yang membangun di atas dasar ideologi dan teknologi Web 2.0, dan yang memungkinkan penciptaan dan pertukaran user-generated content”.

Sedangkan menurut Borgan (Chris Borgan, 2010): "Social media is a new set of communication and collaboration tools that enable many types of interactions that were previously not available to the common person". (Sosial media adalah satu set komunikasi baru dan alat kolaborasi yang memungkinkan banyak tipe interaksi yang mana sebelumnya tidak tersedia untuk orang biasa).

\section{Instagram}

Ferlitasari mengungkapkan, "Instagram merupakan suatu aplikasi yang termasuk dalam media sosial atau lebih tepatnya merupakan jenis jejaring sosial yang digunakan untuk berinteraksi sosial dan mendapatkan informasi melalu foto dan video (Ferlitasari, 2018). Nama instagram berasal dari pengertian keseluruhan fungsi aplikasi ini. Kata "insta" berasal dari kata "instan". Sedangkan untuk kata "gram" berasal dari kata "telegram", di mana cara kerja telegram sendiri adalah untuk mengirimkan informasi kepada orang lain dengan cepat (Ferlitasari, 2018) 
Instagram sebagai media sosial memberikan peluang dan kemudahan bagi seseorang untuk saling berinteraksi meksi tanpa harus bertatap muka. Percakapan-percakapan di instagram biasanya melibatkan suatu topic berupa gambar dan juga video.

Meski terdapat fitur obrolan atau yang disebut dengan direct massage, namun konsep utamanya menekankan pada konten berupa gambar dan video yang bisa disebarkan secara leluasa oleh para penggunanya. Dalam menjalin interaksi, seseorang bisa saling mengikuti atau follow sehingga dapat terhubung lebih dekat satu sama lain. Jika kita melihat suatu foto yang sangat populer di media sosial instagram maka akan itulah yang menjadi pembahasan dengan teman sesama pengguna media Instagram (Irawan \& Yusuf, 2017)

Dalam menjalin interaksi sosial di Instagram, seseorang akan terhubung satu sama lain dengan cara saling mengikuti atau yang disebut dengan "follow", para pengikut suatu akun disebut dengan "followers". Instagram adalah aplikasi yang termasuk dalam media sosial, merupakan jenis jejaring sosial yang digunakan untuk berinteraksi sosial dan mendapatkan informasi melalu foto dan video (Ferlitasari, 2018)

Menurut Bonaditya Instagram adalah sebuah aplikasi berbagi foto yang memungkinkan pengguna mengambil foto, menerapkan filter digital, dan membagikannya ke berbagai layanan jejaring sosial, termasuk milik Instagram sendiri. Satu fitur yang unik di Instagram adalah memotong foto menjadi bentuk persegi, sehingga terlihat seperti hasil kamera kodak instamatic dan polaroid. Hal ini berbeda dengan rasio aspek 4:3 yang umum digunakan oleh kamera pada peranti bergerak (Nasiha, 2017)

Sementara itu Michelle Wifalin menambahkan Instagram adalah sebuah aplikasi media sosial yang memungkinkan pengguna untuk mengambil foto dan video, menerapkan filter digital (pemberian efek pada foto) dan membagikannya ke berbagai media sosial termasuk instagram itu sendiri (Salmiati Salmiati, Yustia Ningsi, 2019)

Berdasarkan pemaparan diatas maka dimensi dari variabel Penggunaan Instagram ini adalah: (1) Frekuensi: Frekuensi dalam menggunakan Instagram sehari-hari; (2) Durasi: Durasi yang dibutuhkan untuk menggunakan Instagram; dan (3) Fitur: Fitur yang sering digunakan saat menggunakan Instagram untuk mengetahui apa saja yang dilakukan pengguna Instagram saat menggunakannya (Ferlitasari, 2018).

\section{Citra Diri}

Citra diri atau self image merupakan gambaran umum tentang diri sendiri yang ingin ditampilkan atau diperlihatkan agar mendapat penilaian atau penghargaan dari orang lain dan lingkungan disekitarnya (Zakirah, 2018).

Dalam banyak hal, citra diri dapat dilakukan melalui berbagai media, salah satunya adalah media sosial. Penggunaan media sosial sebagai media komunikasi juga berhubungan dengan citra orang pengguna media. Citra tersebut merupakan penilaian seseorang atas suatu objek (Rarasingtyas \& Maturbongs, 2019)

Menurut Fitria dan Herlinda, citra diri sendiri yakni gambaran umum tentang diri sendiri atau pandangan yang kita buat untuk diri kita sendiri, mungkin citra diri ini tidak sama dengan kenyataan yang terjadi tetapi kita meyakininya (Zakirah, 2018).

Sedangkan Suneki dan Haryono mengungkapkan, Citra diri dalam kehidupan menurut teori Dramaturgi Goffman adalah ibarat teater, interaksi sosial yang mirip pertunjukan drama, yang menampilkan peran. Dalam memainkan peran menggunakan bahasa verbal dan perilaku non verbal dan mengenakan atribut tertentu. kehidupan sosial dibagi menjadi wilayah depan (front region) yang merujuk peristiwa sosial bahwa individu bergaya menampilkan perannya dan wilayah belakang (back region) yang merujuk tempat dan peristiwa yang memungkinkan mempersiapkan perannya di wilayah depan. Panggung depan dibagi menjadi dua yaitu ; front pribadi (personal front) dan setting atas alat perlengkapan (Suneki \& Haryono, 2017).

Berdasarkan pemaparan diatas, maka dimensi citra diri dalam penelitian ini adalah: (1) Motif atau tujuan diri menggunakan Instagram; (2) Kepuasan yaitu tingkat kepuasan diri dalam menggunakan Instagram; dan (3) Perasaan yakni Perasaan yang dirasakan diri sendiri saat menggunakan Instagram. 
Bagan 1. Kerangka Teori
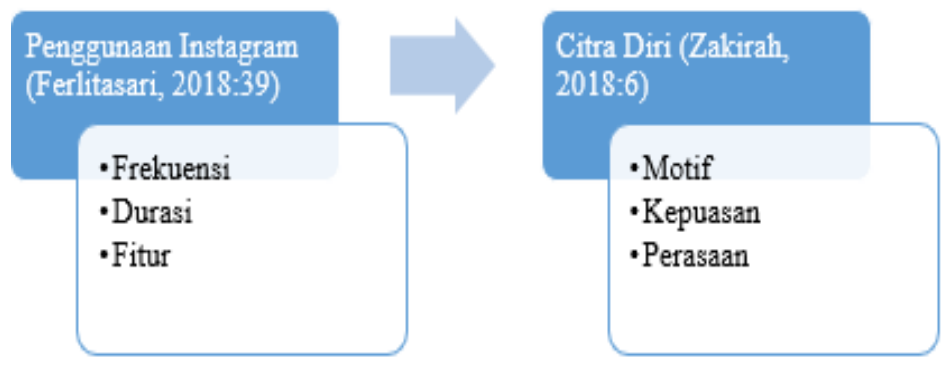

\section{METODE PENELITIAN}

Jenis penelitian yang digunakan yaitu menggunakan metode kuantitatif. Metode ini digunakan karena peneliti ingin mendeskripsikan suatu peristiwa dan gejala yang terjadi terkait penelitian dengan menggunakan data berupa angka dan perhitungan statistic. Dengan melakukan survey berupa kuisioner, penelitian ini akan mendapatkan hasil perolehan data-data yang lengkap dan dapat dijelaskan secara komprehensif. Berikut adalah Operasionalisasi Variabel dalam penelitian ini:

Tabel 1. Operasionalisasi Variabel

\begin{tabular}{|c|c|c|c|}
\hline Variabel & Dimensi & Indikator & No Item \\
\hline \multirow{5}{*}{$\begin{array}{l}\quad(\mathrm{X}) \\
\text { Instagram } \\
\text { (Ferlitasari, } \\
\text { 2018:39) }\end{array}$} & Frekuensi & 1. Frekuensi menggunakan Instagram dalam 1 hari & 1 \\
\hline & & 2. Waktu saat menggunakan Instagram & 2 \\
\hline & Durasi & 3. Lama durasi saat menggunakan Instagram dalam 1 hari & 3 \\
\hline & & 4. Lama durasi saat memposting video/ foto & 4 \\
\hline & Fitur & 5. Fitur yang sering digunakan di Instagram & 5 \\
\hline \multirow{8}{*}{$\begin{array}{l}\text { (Y) } \\
\text { Citra Diri } \\
\text { (Zakirah, } \\
\text { 2018:6) }\end{array}$} & Motif & 6. Motif utama menggunakan Instagram & 6 \\
\hline & & 7. Alasan sering menggunakan Instagram & 7 \\
\hline & Kepuasan & 8. Tingkat kepuasan menggunakan Instagram & 8 \\
\hline & & 9. Nilai besaran kepuasan & 9 \\
\hline & Perasaan & 10. Manfaat yang dirasakan & 10 \\
\hline & & 11. Pengaruh terhadap perasaan & 11 \\
\hline & & 12. Kesenangan menggunakan Instagram & 12 \\
\hline & & 13. Pengaruh Instagram terhadap diri & 13 \\
\hline
\end{tabular}

Populasi dalam penelitian ini adalah mahasiswa Program Studi Manajemen Komunikasi Institut Ilmu Sosial dan Manajemen Stiami yang tercatat aktif pada Semester Ganjil tahun akademik 2019/2020, berjumlah 1230 Mahasiswa (Data dari FORLAP RISTTEKDIKTI). Teknik sampling yang digunakan adalah simple random sampling. Dan dengan menggunakan perhitungan rumus Slovin, maka sampel yang digunakan yakni sejumlah 93 responden, sebagaimana perhitungan berikut ini:

$$
\begin{gathered}
n=\frac{N}{N d^{2}+1} \\
n=\frac{1230}{(1230) 0,1^{2}+1} \\
n=\frac{1230}{13,3} \\
n=\frac{1230}{13,3} \\
n=92,48=93 \text { responden }
\end{gathered}
$$


Penyebaran kuesioner dalam penelitian ini dilakukan menggunakan media google form yang disebar pada platform media sosial whatsapp dan Instagram. Cara penyebaran kuesioner ini dilakukan mengingat pada masa penelitan dilakukan sedang terjadi pandemi wabah virus Covid-19.

\section{HASIL PENELITIAN DAN DISKUSI}

Sebelum pemaparan hasil penelitian, maka berikut adalah hasil pengujian validitas dalam penelitian ini menggunakan bantuan program SPSS 25.00. Syarat minimum untuk dianggap memenuhi syarat bahwa item kuesioner penelitian valid adalah jika nilai $r>r$ tabel, sehingga item soal dianggap valid jika memiliki nilai $r$ lebih besar dari $r$ tabel dan memperoleh nilai signifikansi $<0.05$.

Hasil uji validitas menggunakan pearson product moment pada variabel X Penggunaan Instagram dengan 9 item soal yang diujikan, diperoleh hasil bahwa seluruh item soal memiliki nilai $r>$ 0.202 dan memperoleh nilai signifikansi $<0.05$ maka dapat diambil kesimpulan seluruh item soal valid.

Sedangkan pada uji validitas menggunakan pearson product moment pada 12 item pertanyaan variable Y Citra diri yang diujikan, diperoleh hasil bahwa seluruh item soal memiliki nilai $r>0.202$ dan memperoleh nilai signifikansi $<0.05$ maka dapat diambil kesimpulan seluruh item soal valid.

Selain uji validitas, dilakukan pula uji reliabilitas. Uji reliabilitas pada variabel (X) Instagram terdiri dari 3 dimensi yaitu Frekuensi (frequency), Durasi (duration) dan Fitur (features) dengan 9 item soal yang diujikan. Hasil uji reliabilitas didapatkan nilai cronbach alpha sebesar $0.803>0.6$ maka alat ukur dapat dikatakan reliabel dan termasuk dalam kategori reliabilitas sangat tinggi (Tabel 2).

Tabel 2. Uji Reliabilitas Penggunaan Instagram (X)

\begin{tabular}{cc}
\hline \multicolumn{2}{c}{ Reliability Statistics } \\
\hline \multicolumn{2}{c}{ N of Items } \\
\hline .803 & 9 \\
\hline Sumber: Data primer diolah di SPSS 25.00
\end{tabular}

Sementara, uji reliabilitas pada variabel (Y) Citra Diri terdiri dari 3 dimensi yaitu Motif (Motif), Kepuasan (Satisfaction) dan Perasaan (Feeling) dengan 12 item soal yang diujikan pada variabel (Y) Citra diri. Hasil uji reliabilitas variabel Y dari 12 soal pertanyaan maka didapatkan nilai cronbach alpha sebesar $0.828>0.6$ maka alat ukur dapat dikatakan reliabel dan termasuk dalam kategori reliabilitas sangat tinggi, sebagaimana table 3 dibawah ini:

Tabel 3. Uji Reliabilitas Citra Diri (Y)

\begin{tabular}{cr}
\hline \multicolumn{2}{c}{ Reliability Statistics } \\
\hline Cronbach's Alpha & N of Items \\
\hline .828 & 12 \\
\hline
\end{tabular}

Sumber: Data primer diolah di SPSS 25.00

\section{Hasil Penelitian}

Data identitas responden dimaksudkan untuk mengidentifikasi responden. Responden dalam penelitian ini adalah mahasiswa Program Studi Manajemen Komunikasi Institut Ilmu Sosial dan Manajemen Stiami yang aktif menggunakan Instagram sebanyak 93 orang. Karakteristik responden dalam penelitian ini antara lain meliputi usia dan jenis kelamin. Responden dalam penelitian ini adalah mahasiswa yang berusia 17 sampai 29 tahun keatas. Untuk mempermudah penyajian data maka, rentan umur dibagi ke dalam 5 kelas seperti tabel 4 berikut ini: 
Tabel 4. Usia Responden

\begin{tabular}{crr}
\hline Kategori Usia & \multicolumn{1}{c}{ Frekuensi } & Presentase 100 \% \\
\hline 17 s/d 19 Tahun & 9 & $10 \%$ \\
\hline 20 s/d 23 Tahun & 42 & $45 \%$ \\
\hline 24 s/d 26 Tahun & 28 & $30 \%$ \\
\hline 27 s/d 29 Tahun & 11 & $12 \%$ \\
\hline$>$ 29 Tahun & 3 & $3 \%$ \\
\hline Total & $\mathbf{9 3}$ & $\mathbf{1 0 0 \%}$ \\
\hline
\end{tabular}

Sumber: data hasil kuesioner google form

Dapat dilihat pada tabel 4 dari 93 responden sebagian besar responden yang aktif menggunakan Instagram berusia 20 sampai 23 tahun yaitu sebanyak 45\% responden yang menunjukan bahwa hampir sebagian besar pengguna Instagram terdiri dari kalangan usia muda atau yang disebut sebagai kalangan milenial. Sementara itu urutan kedua terdiri dari responden yang berusia 24 sampai 26 tahun sebanyak 30\%, dimana usia tersebut merupakan kalangan usia muda yang memiliki tingkat kedewasaan lebih matang. Urutan ketiga yaitu terdiri dari usia 27 sampai 29 tahun hanya sebanyak $12 \%$ yang menggambarkan bahwa usia dewasa memiliki ketertarikan yang tidak terlau tinggi terhadap penggunaan Instagram.

Dari data tersebut, dapat dilihat bahwa sebagian besar pengguna Instagram adalah kalangan mahasiswa yang identik sebagai kalangan milenial yakni memiliki rentan usia 17 sampai dengan 26 tahun. Sedangkan jumlah responden yang berusia 27 sampai 29 tahun keatas hanya berjumlah sangat sedikit.

Berdasarkan jenis kelamin, menunjukkan responden perempuan lebih banyak menggunakan Instagram dibandingkan responden laki-laki.

Tabel 5. Jenis Kelamin Responden

\begin{tabular}{lrr}
\hline Jenis Kelamin & Frekuensi & \multicolumn{2}{c}{ Presentase \% } \\
\hline Laki-Laki & 39 & $42 \%$ \\
\hline Perempuan & 54 & $58 \%$ \\
\hline Total & $\mathbf{9 3}$ & $\mathbf{1 0 0 \%}$
\end{tabular}

Sumber: data hasil kuesioner google form

Berdasarkan tabel 5 menunjukan bahwa jumlah responden laki-laki sebanyak $42 \%$ dan perempuan sebanyak 58\%. Hal tersebut dapat diartikan bahwa penggunan Instagram di kalangan mahasiswa lebih banyak digunakan oleh kalangan perempuan.

Selanjutnya, untuk mengukur variabel penggunaan Instagram (X), peneliti menggunakan 3 (tiga) dimensi yaitu frekuensi (frequency), durasi (duration), fitur (features). Kemudian indikatorindikator tersebut dikembangkan menjadi 9 (Sembilan) item pernyataan. Berdasarkan hasil kuesioner diperoleh nilai rata-rata tanggapan atas Penggunaan Instagram dalam kategori baik, sebagaimana tertuang dalam table 6 .

Tabel 6. Hasil rekapitulasi nilai Mean tanggapan responden terhadap variabel Penggunaan Instagram

\begin{tabular}{lllc}
\hline Dimensi & Indikator & Nilai & Interpretasi \\
\hline $\begin{array}{l}\text { Frekuensi } \\
\text { Frequency) }\end{array}$ & 1. Sering menggunakan Instagram dalam 1 hari & 4.15 & Baik \\
\cline { 2 - 4 } & 2. Menggunakan Instagram lebih dari 1 kali dalam sehari & 4.14 & Baik \\
\cline { 2 - 4 } & 3. Sering menggunakan Instagram disaat waktu luang & 4.26 & Sangat baik \\
\hline $\begin{array}{l}\text { Durasi } \\
\text { (Duration) }\end{array}$ & $\begin{array}{l}\text { 4. Menggunakan Instagram lebih dari 1 jam dalam sehari } \\
\text { 5. Membutuhkan waktu lebih dari 1 jam untuk memposting } \\
\text { video/ foto }\end{array}$ & 3.74 & Baik \\
\hline $\begin{array}{l}\text { 3. Fitur } \\
\text { (Features) }\end{array}$ & 6. Menggunakan fitur membagikan foto/ video & 2.97 & Cukup baik \\
\cline { 2 - 4 } & 7. Menggunakan fitur direct massage & 3.78 & Baik \\
\hline
\end{tabular}




\begin{tabular}{lll} 
8. Menggunakan fitur like dan comment & 4.11 & Baik \\
\hline 9. Menggunakan banyak fitur & 3.70 & Baik \\
\hline TOTAL & $\mathbf{3 4 . 7 5}$ & \\
\hline Rata-rata penafsiran $=\mathbf{3 4 . 7 5 / 9}=\mathbf{3 . 8 6}$ & $\mathbf{3 . 8 6}$ & BAIK
\end{tabular}

Dari perhitungan rekapitulasi tabel di atas diperoleh bahwa untuk interpretasi keseluruhan indikator adalah baik dengan nilai tertinggi diperoleh indikator sering menggunakan Instagram disaat waktu luang dengan jumlah 4,26 dan nilai terendah di peroleh indikator membutuhkan waktu lebih dari 1 jam untuk memposting video/foto dengan jumlah 2,97. Sehingga pada skala interval ini telah ditentukan bahwa hasil angka penafsiran untuk variabel Penggunaan Instagram sebesar 3.86 dan angka tersebut termasuk skala 3,41-4,20 dengan kriteria penilaian Baik.

Berikutnya dalam mengukur variabel Citra Diri (Y), peneliti menggunakan 3 (tiga) dimensi yaitu motif (motif), kepuasan (satisfaction), perasaan (feeling). Kemudian indikator-indikator tersebut dikembangkan menjadi 12 (Dua Belas) item pernyataan. Berdasarkan perhitungan nilai rata-rata diperoleh bahwa Citra Diri dalam kategori baik, sebagaimana table 7 dibawah.

Tabel 7. Hasil rekapitulasi nilai Mean tanggapan responden terhadap variabel Citra Diri

\begin{tabular}{|c|c|c|c|}
\hline Dimensi & Indikator & Nilai & Interpretasi \\
\hline \multirow{6}{*}{$\begin{array}{l}\text { Motif } \\
\text { (Motif) }\end{array}$} & 1. Menggunakan Instagram untuk eksistensi diri & 3.41 & Baik \\
\hline & 2. Menggunakan Instagram untuk pertemanan & 4.14 & Baik \\
\hline & 3. Menggunakan Instagram untuk mendapatkan Informasi & 4.44 & Sangat baik \\
\hline & 4. Menggunakan Instagram karena hobi & 3.31 & Cukup baik \\
\hline & 5. Menggunakan Instagram sebatas hiburan & 4.11 & Baik \\
\hline & 6. Menggunakan Instagram karena kebutuhan & 3.46 & Baik \\
\hline \multirow{2}{*}{$\begin{array}{l}\text { Kepuasan } \\
\text { (Satisfaction) }\end{array}$} & 7. Sangat puas menggunakan Instagram & 3.96 & Baik \\
\hline & 8. Memberikan nilai 10 untuk kepuasan menggunakan Instagram & 3.76 & Baik \\
\hline \multirow{6}{*}{$\begin{array}{l}\text { Perasaan } \\
\text { (Feeling) }\end{array}$} & 9. Banyak manfaat yang dirasakan saat menggunakan Instagram & 3.94 & Baik \\
\hline & 10. Instagram mempengaruhi perasaan setiap kali menggunakannya & 3.75 & Baik \\
\hline & 11. Sangat senang menggunakan Instagram & 3.81 & Baik \\
\hline & 12. Menggunakan Instagram memberikan perubahan dalam diri & 3.41 & Baik \\
\hline & TOTAL & 45.49 & \\
\hline & Rata-rata penafsiran $=45.49 / 12=3.79$ & 3.79 & Baik \\
\hline
\end{tabular}

Dari perhitungan rekapitulasi tabel 7 , diperoleh bahwa untuk interpretasi keseluruhan indikator adalah baik dengan nilai tertinggi diperoleh indikator menggunakan Instagram untuk mendapatkan Informasi dengan jumlah 4,44 dan nilai terendah di peroleh indikator menggunakan Instagram karena hobi dengan jumlah 3,31. Sehingga pada skala interval ini telah ditentukan bahwa hasil angka penafsiran untuk variabel Citra diri sebesar 3.79 dan angka tersebut termasuk skala 3,414,20 dengan kriteria penilaian Baik.

Tabel 8. Uji Korelasi

\begin{tabular}{|c|c|c|c|}
\hline \multicolumn{4}{|c|}{ Correlations } \\
\hline & & ram & citra diri \\
\hline \multirow[t]{3}{*}{ penggunaan Instagram } & Pearson Correlation & 1 & $.799^{* * *}$ \\
\hline & Sig. (2-tailed) & & .000 \\
\hline & $\mathrm{N}$ & 93 & 93 \\
\hline \multirow[t]{3}{*}{ Citra diri } & Pearson Correlation & $.799^{* *}$ & 1 \\
\hline & Sig. (2-tailed) & .000 & \\
\hline & $\mathrm{N}$ & 93 & 93 \\
\hline
\end{tabular}


Selanjutnya, berdasarkan output uji korelasi antara variable Penggunaan Instagram dan Citra Diri menunjukkan dengan nilai signifikansi sebesar $0.000<0,05$ diperoleh hasil bahwa terdapat hubungan positif signifikan antara penggunaan instagram $(\mathrm{X})$ dengan citra diri $(\mathrm{Y})$ dengan nilai korelasi sebesar 0.799 yang dapat dikategorikan dalam hubungan dengan tingkat yang kuat (Tabel 8).

Tabel 9. Hasil Uji Determinasi

\begin{tabular}{|c|c|c|c|}
\hline \multicolumn{2}{|r|}{ Model Summary } & & \\
\hline Model & R $\quad$ R Square & Adjusted R Square & $\begin{array}{l}\text { Std. Error of the } \\
\text { Estimate }\end{array}$ \\
\hline & $1.799^{\mathrm{a}}$ & .634 & 3.71698 \\
\hline
\end{tabular}

Sumber: Data primer diolah di SPSS 25.00

Berdasarkan output diatas didapatkan nilai $\mathrm{R}$ square sebesar 0.638 , hal ini menunjukkan bahwa penggunaan instagram mempengaruhi citra diri sebesar 63.8\% (Tabel 9).

Analisis pengujian parsial (Uji t) diperlukan untuk mengetahui bahwa variabel independen mempunyai pengaruh yang signifikan terhadap variabel dependen. Pengambilan keputusan dalam uji ini didasarkan pada tingkat signifikansi sebesar 5\% atau 0,05. Hasil uji T dapat dilihat pada table 10 di bawah ini:

Tabel 10. Uji T

\begin{tabular}{|c|c|c|c|c|c|}
\hline \multicolumn{6}{|l|}{ Coefficients $^{\mathrm{a}}$} \\
\hline \multirow[t]{2}{*}{ Model } & Unstandardiz & d Coefficients & Standardized Coefficients & \multirow[t]{2}{*}{$\mathrm{t}$} & \multirow[t]{2}{*}{ Sig. } \\
\hline & $\mathrm{B}$ & Std. Error & Beta & & \\
\hline (Constant) & 12.178 & 2.658 & & 4.582 & .000 \\
\hline penggunaan instagram & .959 & .076 & .799 & 12.670 & .000 \\
\hline
\end{tabular}

a. Dependent Variable: Citra diri

Sumber: Data primer diolah di SPSS 25.00

Penggunaan instagram memperoleh nilai t hitung sebesar 12.670 dan t tabel sebesar 1.990 .

Nilai T tabel didapatkan dari:

T tabel $=($ alfa $/ 2 ; \mathrm{n}-\mathrm{k}-1)$

$\mathrm{T}$ tabel $=(0,05 / 2 ; 93-1-1)$

T tabel $=(0,025 ; 91)$

$\mathrm{T}$ tabel $=1.990$

Dari data tersebut menunjukkan bahwa penggunaan Instagram memperoleh nilai t hitung lebih besar dari nilai t tabel yaitu $12.670>1.990$ dan nilai signifikansi sebesar $0.000<0.05$. Hal ini menunjukkan bahwa penggunaan instagram berpengaruh positif signifikan terhadap citra diri, artinya semakin tinggi penggunaan instagram maka semakin tinggi juga citra diri.

Selanjutnya berdasarkan output uji $\mathrm{T}$ di atas diperoleh nilai 12.178 maka dapat dirumuskan persamaan regresi linear sederhana pada penelitian ini sebagai berikut:

Tabel 11. Regresi Sederhana

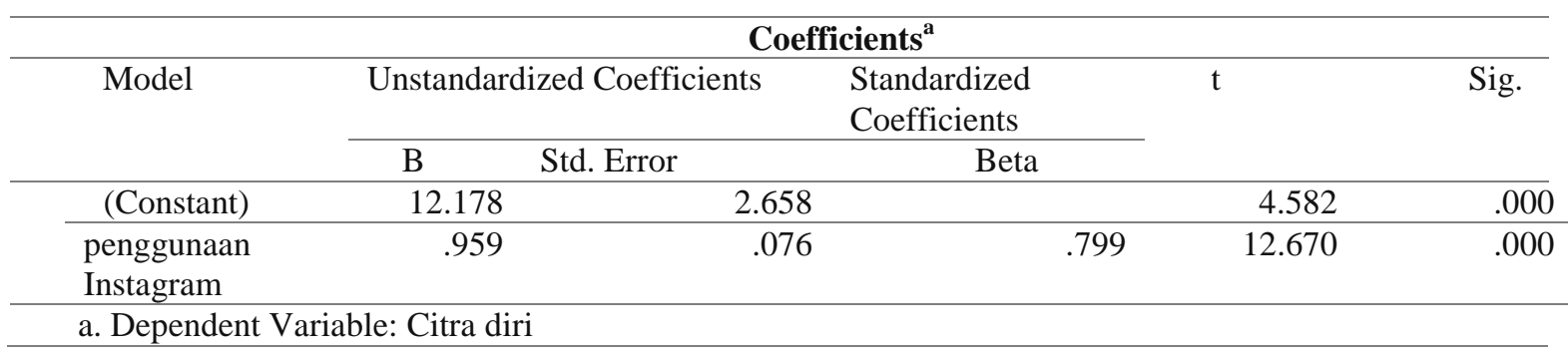

Sumber: Data primer diolah di SPSS 25.00 


\section{$Y=12.178+0.959 X$}

Nilai konstanta diperoleh nilai sebesar 12.178 artinya jika tidak ada penggunaan instagram maka nilai konstan dari citra diri adalah sebesar 12.178. Angka koefisien regresi dari penggunaan instagram adalah sebesar 0.959 , artinya setiap penambahan $1 \%$ dari penggunaan instagram maka nilai dari citra diri akan meningkat sebesar 0.959 .

\section{Diskusi}

Penelitian ini dilakukan untuk mengetahui seberapa besar pengaruh penggunaan Instagram terhadap Citra diri mahasiswa. Berdasarkan teori tentang citra diri yaitu teori Dramatugi yang dikemukakan Goffman, maka seseorang tidak lepas dari pengaruh Cooley tentang the looking glass self, yang terdiri dari bagaimana kita tampil bagai orang lain dan bagaimana penilaian orang lain terhadap diri sendiri yang akhirnya kita mengembangkan perasaan diri, seperti malu, bangga, sebagai akibat mengembangkan penilaian orang lain.

Teori Dramatugi pun sangat berkaitan erat dengan penggunaan Instagram yang dilakukan seseorang sehingga mempengaruhi citra dirinya. Hal itupun terbukti dengan dilakukannya uji analisa pada mahasiswa Institut Stiami sebanyak 93 orang sebagai sampel dalam penelitian.

Setelah dilakukan uji analisis menggunakan koefiensi determinasi didapatkan hasil bahwa terdapat pengaruh atau hubungan yang cukup signifikan antara penggunaan Instagram terhadap citra diri yaitu dengan presentasi sebesar $63,8 \%$.

Besarnya presentase tersebut sangat sesuai dengan konsep Instagram yang memang sangat digemari oleh kalangan muda seperti mahasiswa yang merasa senang dan puas saat menggunakan Instagram. Media sosial Instagram tidak hanya sekedar digunakan sebagai sarana untuk berkomunikasi atau mencari informasi, namun hampir setiap orang memanfaatkannya sebagai sarana untuk eksistensi diri yang dapat menimbulkan suatu persepsi atau penilaian tentang citra diri.

Konsep Instagram yang instan dan mudah untuk digunakan sangat identik dengan karakter kalangan muda yang menyukai hal-hal berbau instan. Dengan beragam fitur modern yang lengkap setiap pengguna Instagram bisa menggambarkan tentang citra diri nya melalui suatu konten foto ataupun video yang di uploadnya di Instagram.

Besarnya pengaruh penggunaan Instagram membuat seseorang memiliki perubahan dalam diri yang menimbulkan banyak persepsi serta penilaian orang lain terhadap dirinya. Eksistensi diri serta penilaian orang lain menjadikan penggunaan Instagram menjadi sangat penting hingga intensitas penggunaannya pun menjadi sangat tinggi.

Uji hipotesis penggunaan Instagram memperoleh nilai $t$ hitung lebih besar dari nilai $t$ tabel yaitu $12.670>1.990$ dan nilai signifikansi sebesar $0.001<0.05$, sehingga angka tersebut menunjukan bahwa penggunaan instagram berpengaruh positif signifikan terhadap citra diri, artinya semakin tinggi penggunaan instagram maka semakin tinggi juga citra diri.

Setiap pengguna Instagram merasa sangat puas dan senang setiap kali mengupload foto ataupun video yang menggambarkan dirinya. Dengan adanya fitur follow dan unfollow setiap orang bisa dengan leluasa menjalin pertemanan dan hubungan sosial yang sangat luas, hal tersebut dibuktikan dengan adanya hasil nilai data variabel pada indikator yang menunjukan bahwa hampir setiap responden di kalangan mahasiswa menggunakan Instagram dengan motif untuk menjalin pertemanan dengan nilai sebesar 4.14 dan dikategorikan sebagai nilai yang baik.

Fitur pertemanan di Instagram tentu menjadikan setiap penggunanya semakin antusias untuk mendapatkan penilaian dari setiap postingan foto ataupun video dalam akun pribadinya. Meskipun terkadang citra dirinya di Instagram sangat bertolak belakang dengan dirinya di dunia nyata.

Hal itupun yang dijelaskan dalam Dramatugi tentang konsep citra diri yang dikemukakan oleh Goffman, dimana seseorang menjalani kehidupan layaknya seperti dalam panggung drama atau sebuah teater yang menunjukan citra diri berbeda antara di depan panggung dan di belakang panggung. Hal itulah yang kini terjadi saat seseorang menggunakan Instagram dimana penggunaannya memiliki pengaruh yang cukup signifikan terhadap citra diri.

Berdasarkan nilai variabel pada indikator penelitian yang dilakukan penggunaan Instagram ternyata benar- benar memiliki pengaruh yang cukup besar dimana hampir setiap responden menyatakan bahwa mereka sangat senang dan puas setiap kali menggunakan Instagram dengan perolehan nilai rata-rata sebesar 3.96 dan 3.81 dan dikategorikan sebagai nilai yang baik. 
Meskipun demikian, dari 93 responden mahasiswa didapatkan bahwa tidak semua menggunakan Instagram sebagai sarana untuk eksistensi diri ataupun menjalin pertemanan yang dapat mempengaruhi citra diri. Beberapa orang menggunakan Instagram hanya sebatas sebagai hiburan dan sarana untuk mencari Informasi. Hal itupun tentu saja tidak akan berpengaruh signfikan terhadap citra dirinya. Saat penggunaan Instagram dilakukan tanpa ada unsur untuk eksistensi diri atau untuk mendapat kepuasan dalam diri maka tidak akan timbul citra diri yang buruk dari orang lain.

Namun tentu saja citra diri seseorang akan tergambarkan tergantung dari bagaimana ia berperilaku dan menampilkan dirinya, baik dalam Instagram maupun dalam kesehariannya di dunia nyata. Sehingga sudah seharusnya jika penggunaan Instagram tidak dilakukan secara berlebihan terutama untuk hal-hal yang berbau negatif yang akan menimbulkan kontraversi penilaian buruk dari orang lain.

\section{SIMPULAN}

Berdasarkan hasil penelitian diatas, dapat ditarik kesimpulan bahwa Instagram berpengaruh signifikan terhadap citra diri mahasiswa. Seseorang membentuk citra dirinya yang berbeda dengan kehidupannya didunia nyata. Penggunaan Instagram tidak hanya digunakan sebagai media untuk berkomunikasi, namun memberikan pengaruh yang sangat besar terhadap pembentukan citra. Dalam penelitian ini besar pengaruh penggunaan Instagram menunjukan hasil yang positif, dibuktikan pada uji $\mathrm{T}$ (uji hipotesis) dengan $\mathrm{t}$ hitung sebesar 12.670 yang lebih besar dari nilai $\mathrm{t}$ tabel sebesar 1.990 sehingga hipotesis H1 diterima. Pada uji korelasi product moment atau sering disebut Product Moment Pearson, uji korelasi diperoleh nilai signifikansi sebesar $0.000<0,05$ sehingga menyatakan bahwa terdapat hubungan positif signifikan antara penggunaan instagram $(\mathrm{X})$ dengan citra diri $(\mathrm{Y})$ dengan nilai korelasi sebesar 0.799 yang dapat dikategorikan dalam hubungan dengan tingkat yang kuat. Hasil uji koefiensi determinasi menunjukan pengaruh penggunaan Instagram terhadap citra diri memiliki presentase yang cukup tinggi yakni bahwa penggunaan instagram mempengaruhi citra diri sebesar $63.8 \%$.

Berdasarkan temuan diatas maka, penelitian ini merekomendasikan khususnya pada mahasiswa agar cerdas menggunakan Instagram. Meskipun durasi untuk mengupload foto atau foto dirasa sangat singkat, namun hal tersebut tentu bukan menjadi celah untuk sering menggunakan Instagram sebagai alat eksistensi diri. Gunakanlah Instagram untuk hal-hal yang lebih bermanfaat seperti untuk berbisnis, mencari informasi dan kegiatan postif lainnya. Selain itu, hendaklah dapat lebih bijak dalam menggunakan Instagram tanpa harus menjadikannya sebagai suatu kebutuhan ataupun hobi. Berikan batasan pada diri agar tidak berlebihan menggunakan Instagram yang akhirnya membuat perubahan dalam diri yang menjadi tidak terkontrol. Selanjutnya penulis merekomendasikan untuk dilakukan kajian dengan pendekatan kualitatif terkait penggunaan media sosial Instagram khususnya dalam membangun citra diri.

\section{DAFTAR PUSTAKA}

[1] Cahyono, A. S. (2016). Anang Sugeng Cahyono, Pengaruh Media Sosial Terhadap Perubahan Sosial Masyarakat di Indonesia. Jurnal Publiciana, 140-157.

[2] Chris Borgan. (2010). Social Media 101. In Wiley (Ed.), Powers of Freedom (First Edit). John Wiley and Sons, Inc., Hoboken, New Jersey. https://doi.org/https://doi.org/10.1017/cbo9780511488856.004

[3] Ferlitasari, R. (2018). Pengaruh Media Sosial Instagram Terhadap Perilaku Keagamaan Remaja. 61. http://repository.radenintan.ac.id/4221/1/SKRIPSI.pdf

[4] Irawan, E., \& Yusuf, Y. (2017). Instagram Sebagai Gaya Hidup Masyarakaat Kota Pekanbaru (Studi Komuniktas Instagram di Kota Pekanbaru). JOM FISIP, 4(2), 1-14.

[5] Nasiha, N. F. (2017). PENGARUH PENGGUNAAN MEDIA SOSIAL INSTAGRAM TERHADAP CITRA TUBUH MAHASISWA FAKULTAS USHULUDDIN ADAB DAN DAKWAH IAIN PONOROGO TAHUN 2016. Dialogia, 15(2), 337-355.

[6] Putri, N. S. R., \& Farida, F. (2018). Pembentukan Citra Diri Mahasiswa Fakultas Ilmu Komunikasi Universitas dr. Soetomo Surabaya dalam Instagram. Jurnal Kajian Media, 2(2), 120-130. https://doi.org/10.25139/jkm.v2i2.1380

[7] Rarasingtyas, I. I., \& Maturbongs, Y. H. (2019). Pengaruh Motif Penggunaan Media Instagram Terhadap Citra Diri Pt XYZ. Communication and Bussiness, 5, 123-149. 
[8] Restusari, F. N., \& Farida, N. (2019). Instagram Sebagai Alat Personal Branding Dalam Membentuk Citra Diri (Studi Pada Akun Bara Pattiradjawane). Mediakom : Jurnal Ilmu Komunikasi, 3(2), 176-186. https://doi.org/10.35760/mkm.2019.v3i2.2340

[9] Salmiati Salmiati, Yustia Ningsi, R. R. (2019). Pengaruh Penggunaan Instagram Terhadap Karakter Peserta Didik di Kelas X SMA Negeri 3 Pare Pare. JPPI (Jurnal Pendidikan Islam Pendekatan Interdisipliner), 3(1), 73-85.

[10] Sharma, S., \& Sahu, D. (2013). Effect of Social Networking Sites on Academic. Asian Journal of Social Sciences \& Humanities, 2(3), 401-406.

[11] Suneki, \& Haryono. (2017). Paradigma Teori Dramaturgi Terhadap Kehidupan Sosial. Civis, 2(2), 1-11.

[12] Zakirah, D. M. A. (2018). Mahasiswa dan Instagram (Study Tentang Instagram Sebagai Sarana Membentuk Citra Diri di Kalangan Mahasiswa Universitas Airlangga). Jurnal S1 Sosiologi FISIP Universitas Airlangga, 1-21. 